\title{
Antioxidant Activity and Phenolic Composition of Brazilian Honeys and their Extracts
}

\author{
Regina L. P. Lianda, ${ }^{a, b}$ Luiza D'Oliveira Sant'Ana, ${ }^{a}$ Aurea Echevarria ${ }^{a}$ and Rosane N. Castro ${ }^{*, a}$ \\ ${ }^{a}$ Departamento de Química, Instituto de Ciências Exatas, Universidade Federal Rural do \\ Rio de Janeiro, Rodovia BR 465, km 47, 23890-000 Seropédica-RJ, Brazil \\ ${ }^{b}$ Núcleo de Química, Instituto Federal Sudeste de Minas Gerais, Rua Monsenhor José Augusto, 204, \\ 36205-018 Barbacena-MG, Brazil
}

\begin{abstract}
Foram avaliadas as atividades antioxidantes e o conteúdo de polifenóis de cinco méis silvestres e quatro de laranjeira, bem como de seus extratos fenólicos. A identificação e quantificação das substâncias fenólicas foram realizadas por HPLC-DAD (cromatografia líquida de alta eficiência com detecção por arranjo de diodos). A atividade sequestradora de radicais livres, determinada por 2,2-difenil-1-picrilhidrazil (DPPH') e expressa como $\mathrm{CE}_{50}$, variou de 10,81 a $52,64 \mathrm{mg} \mathrm{mL}^{-1}$ para mel e de 6,17 a $52,87 \mu \mathrm{g} \mathrm{mL}^{-1}$ para extrato. A atividade antioxidante dos extratos foi também determinada pelos métodos com 2,2'-azinobis-(3-etil-benzotiazolino-6-ácido sulfônico) sal diamônio (ABTS) e poder antioxidante de redução do ferro (FRAP), e os resultados variaram de 46,53 a 383,49 mmol TE $100 \mathrm{~g}^{-1}$ e de 34,99 a 408,14 mol Fe(II) $100 \mathrm{~g}^{-1}$, respectivamente. Também foram avaliados os teores de fenóis totais e flavonóides pelos métodos de Folin-Denis e complexação com cloreto de alumínio, respectivamente. A atividade antioxidante e o teor de fenóis totais mostraram-se altamente correlacionáveis.
\end{abstract}

The antioxidant activities and total polyphenolic content of five multifloral and four orange blossom Brazilian honey samples and their phenolic extracts were investigated. Identification and quantification of phenolic compounds were carried out by HPLC-DAD (high-performance liquid chromatography with diode-array detection). The radical scavenging activities, determined with 2,2-diphenyl-1-picrylhydrazyl ( $\mathrm{DPPH}^{\circ}$ ) and expressed as $\mathrm{EC}_{50}$, ranged from 10.81 to $52.64 \mathrm{mg} \mathrm{mL}^{-1}$ for honey and 6.17 to $52.87 \mu \mathrm{g} \mathrm{mL}^{-1}$ for the extracts. The extract antioxidant activities were also determined by 2,2'-azino-bis-(3-ethylbenzothiazoline-6-sulfonic acid) diammonium salt (ABTS) and ferric reducing antioxidant power (FRAP) assays, and the results varied from 46.53 to $383.49 \mathrm{mmol} \mathrm{TE} 100 \mathrm{~g}^{-1}$ and 34.99 to $408.14 \mathrm{~mol} \mathrm{Fe}$ (II) $100 \mathrm{~g}^{-1}$, respectively. It was also evaluated the total phenolic and flavonoid contents by the Folin-Denis and aluminum chloride methods, respectively. Antioxidant activities and total phenolic contents were found to be highly correlated.

Keywords: orange blossom Brazilian honey, multifloral Brazilian honey, honey phenolic compounds

\section{Introduction}

Honey is the most important primary product of beekeeping, both from a quantitative and an economic point of view, and honey has been used throughout much of history. Honey from Apis mellifera is undoubtedly the most widely collected honey, and this variety has been spread around the world. The quality of honey is judged by the botanical or floral origin of the honey as well as its chemical composition. ${ }^{1}$ Sugars and water represent the main

\footnotetext{
*e-mail: nora@ufrrj.br
}

chemical constituents of honey (95\%), whereas proteins, vitamins, amino acids, phenolic acids and flavonoids constitute the minor components. ${ }^{2}$ Honey is rich in phenolic compounds, which act as natural antioxidants, and are becoming increasingly popular because of their potential role in contributing to human health. These compounds can also be used as indicators in studies into the floral and geographical origins of honey.

The use of analytical procedures for determination of phenolic acids or flavonoids, individually or as a group simultaneously, has been related to the floral and geographical origins of honey. ${ }^{3}$ 
Honey is known to be rich in both enzymatic and nonenzymatic antioxidants, including glucose oxidase, ascorbic acid, flavonoids, phenolic acids, carotenoid derivatives, organic acids, amino acids and proteins. ${ }^{4}$ According to previous literature, honey composition and antioxidant capacity depend on the nectar floral source. In addition, seasonal and environmental factors as well as processing may also have an effect on honey composition and antioxidant activity. ${ }^{5}$

Previous studies indicate that among minor honey constituents, polyphenols such as phenolic acids and flavonoids may function as natural antioxidants in our diet. $^{6}$ These antioxidants can play an important role in food preservation and human health by combating damage caused by oxidizing agents. For this reason, honey has recently received much attention.

Several studies on the phenolic composition have been carried out in European honeys, ${ }^{7}$ however, little information is available on the phenolic profiles of Brazilian honeys.

The aim of this study was identify and quantify phenolic compounds in nine Brazilian honeys and to determine their antioxidant activities, as well as on their phenolic extracts.

\section{Experimental}

Honey samples

Nine Apis mellifera honey samples were collected for this study (Table 1). Four samples of multifloral honeys (RLS1, RLS2, RLS3 and RLS4) and three samples of orange blossom honey (RLL1, RLL2 and RLL3) were obtained from beekeepers. Two samples of orange blossom honey (RLL4 and RLL5) were purchased from the local market. The samples were collected between June 2003 and March 2004 from different geographical regions of Rio de Janeiro and São Paulo States (Table 1). The botanical origin was confirmed by the traditional qualitative microscopic analysis and frequency determination of the classes of pollen grains in the honey samples. ${ }^{8}$ The honey was considered as monofloral when more than $45 \%$ of typical pollen grains of the botanical specie was present. ${ }^{8}$ Samples were stored at $4{ }^{\circ} \mathrm{C}$ until they were analyzed.

\section{Phenolic extractions}

The procedure for the fractionation of honey was carried out as previously described. ${ }^{3,6,9}$ Honey samples $(50 \mathrm{~g})$ were thoroughly mixed with $250 \mathrm{~mL}$ of distilled water and adjusted to $\mathrm{pH} 2$ with concentrated $\mathrm{HCl}$ and filtered through cotton to remove solid particles. The filtrate was mixed with $75 \mathrm{~g}$ of Amberlite XAD-2 resin, pore size $9 \mathrm{~nm}$ and particle size 0.3-1.2 mm (Supelco, Bellefonte, PA, USA) and magnetically stirred for $10 \mathrm{~min}$. The mixture was then packed into a glass column $(25 \times 2.0 \mathrm{~cm})$. The column was washed with $250 \mathrm{~mL}$ of acidified water $(\mathrm{pH} 2$ with $\mathrm{HCl}$ ) and then subsequently rinsed with $300 \mathrm{~mL}$ of neutral distilled water to remove all sugars and other polar compounds of honey. The phenolic compounds were eluted from the sorbent with $500 \mathrm{~mL}$ of methanol. The methanol extracts were concentrated under vacuum at $40{ }^{\circ} \mathrm{C}$ in a rotary evaporator. The residue was dissolved in $10 \mathrm{~mL}$ of distilled water and extracted five times with $10 \mathrm{~mL}$ of ethyl acetate. The extracts were combined and the solvent was removed under vacuum. The dried residue was then redissolved in $1 \mathrm{~mL}$ of methanol (HPLC grade) and filtered through a $0.45 \mu \mathrm{m}$ pore size membrane filter (Sartorius Stedim Biotech, Germany). Three replicate extractions were performed for each sample, and the standard deviation did not exceed $5 \%$. The yields of extracts were expressed as a mean of three extractions and ranged from 10 to $53 \mathrm{mg}$ per $50 \mathrm{~g}$ of product.

\section{Determination of total phenolic content}

The modified Folin-Dennis method ${ }^{10}$ was used to determine the total phenolic content. Each honey sample

Table 1. Honey samples analyzed in this work

\begin{tabular}{|c|c|c|c|c|}
\hline Sample code & Kind of honey & Botanical origin ( $\%$ of pollen) & Harvest date & Localization \\
\hline RLS1 & multifloral & multifloral & March 2004 & Paraty-RJ \\
\hline RLS2 & multifloral & multifloral & December 2003 & Itararé-SP \\
\hline RLS3 & multifloral & multifloral & January 2004 & Itararé-SP \\
\hline RLS4 & multifloral & multifloral & March 2004 & Juquitiba-SP \\
\hline RLL1 & orange blossom & Citrus sp & March 2004 & Botucatu-SP \\
\hline RLL2 & orange blossom & Citrus sp & March 2004 & Botucatu-SP \\
\hline RLL3 & orange blossom & Citrus sp & March 2004 & Itararé-SP \\
\hline RLL4 & orange blossom & Citrus sp & June 2003 & Niterói-RJa \\
\hline RLL5 & orange blossom & Citrus sp & March 2004 & Botucatu-SPa \\
\hline
\end{tabular}

abtained from local markets. 
$(100 \mathrm{mg})$ and each phenolic extract $(0.1 \mathrm{mg})$ were diluted to $1.0 \mathrm{~mL}$ with distilled water. Each solution $(0.5 \mathrm{~mL})$ was then mixed with $2.5 \mathrm{~mL}$ of Folin-Denis reagent (Sigma-Aldrich Chemie, Steinheim, Germany), and after $5 \mathrm{~min}, 2 \mathrm{~mL}$ of a $14 \%$ sodium carbonate $\left(\mathrm{Na}_{2} \mathrm{CO}_{3}\right)$ solution was added. After incubation at room temperature for $2 \mathrm{~h}$, the absorbance of the reaction mixture was measured at $760 \mathrm{~nm}$ against a Milli-Q water blank using a Shimadzu spectrophotometer (UVmini-1240, Japan). Gallic acid (Sigma-Aldrich Chemie, Steinheim, Germany) was used as the standard to produce the calibration curve $\left(0-0.022 \mathrm{mg} \mathrm{mL}^{-1}\right.$, $y=4.75098 x+23.73359, R=0.99313)(R$ : correlation coefficient). The mean of three analyses was used, and the total phenolic content was expressed in gallic acid equivalents (mg GAE $100 \mathrm{~g}^{-1}$ of honey or g GAE $100 \mathrm{~g}^{-1}$ of extract).

\section{Determination of total flavonoid content}

Total flavonoid content was determined using a colorimetric method as previously described. ${ }^{11}$ Briefly, $3 \mathrm{~mL}$ of a $2 \%$ aluminum trichloride $\left(\mathrm{AlCl}_{3}\right.$; Vetec, Brazil) methanolic solution were added to the same volume of honey (300-600 mg mL $\mathrm{mL}^{-1}$ in methanol:water) or extract $\left(0.2 \mathrm{mg} \mathrm{mL} \mathrm{m}^{-1}\right.$ in methanol) solution. After $30 \mathrm{~min}$ of incubation, the absorbance values were measured at $415 \mathrm{~nm}$ against a methanol (HPLC grade) blank. Quercetin (SigmaAldrich Chemie, Steinheim, Germany) was used as a standard to produce the calibration curve $\left(0-0.020 \mathrm{mg} \mathrm{mL}^{-1}\right.$, $y=6.95836 x+27.0114, R=0.99296)$. The total flavonoid content was calculated from the mean of three analyses and expressed as quercetin equivalents (mg QE $100 \mathrm{~g}^{-1}$ of honey or g QE $100 \mathrm{~g}^{-1}$ of extract).

\section{Determination of free radical scavenging activity with DPPH (2,2-diphenyl-1-picrylhydrazyl)}

The scavenging activity of honey samples and extracts for the radical DPPH (Sigma-Aldrich Chemie, Germany), was measured as described by Zhang and Hamauzu ${ }^{12}$ with some modifications. The purple color of 2,2-diphenyl1-picrylhydrazyl (DPPH) decays in the presence of an antioxidant, and the change in the absorbency can be spectrophotometrically monitored at $517 \mathrm{~nm}$.

A volume of $29 \mu \mathrm{L}$ of a $0.3 \mathrm{mmol} \mathrm{L}^{-1} \mathrm{DPPH}$ methanolic solution was added to $71 \mu \mathrm{L}$ of various concentrations of honey (5 to $50 \mathrm{mg} \mathrm{mL}^{-1}$ in water:methanol $1: 1$ ), honey extract (5 to $100 \mu \mathrm{gL} \mathrm{m}^{-1}$ in methanol) or phenolic standard ( 5 to $500 \mu \mathrm{mol} \mathrm{L}^{-1}$ in methanol). The mixtures were kept in the dark for $30 \mathrm{~min}$ at room temperature, and the absorbance of the remaining DPPH was determined at $517 \mathrm{~nm}$ using a microplate reader. ${ }^{13}$ A mixture of $29 \mu \mathrm{L}$ of honey, extract or standard solution was used as a blank, and a mixture of $29 \mu \mathrm{L}$ of DPPH solution with $71 \mu \mathrm{L}$ of methanol was used as a negative control. The radical scavenging activity was calculated as percentage of DPPH discoloration using equation 1 :

AA $\%=100-\left(\frac{\mathrm{Abs}_{\text {sample }}-\mathrm{Abs}_{\text {blank }}}{\mathrm{Abs}_{\text {control }}}\right) \times 100$

where $\mathrm{AA} \%=$ inhibition percentage, $\mathrm{Abs}_{\text {blank }}=$ average absorption of a blank sample at the end of the reaction, $\mathrm{Abs}_{\text {sample }}=$ average absorption of a tested honey, honey extract or phenolic standard at the end of the reaction, and $\mathrm{Abs}_{\text {control }}=$ average absorption of negative control at the end of the reaction.

The effective concentration providing 50\% inhibition $\left(\mathrm{EC}_{50}\right)$ was calculated from the graph of scavenging effect percentage against honey, honey extract or phenolic standard concentration. All experiments were carried out in triplicate.

Determination of antioxidants using ABTS [2,2'-azino-bis(3-ethylbenzothiazoline-6- sulfonic acid) diammonium salt]

The $\mathrm{ABTS}^{-+}$radical was prepared by mixing $5 \mathrm{~mL}$ of an aqueous $7 \mathrm{mmol} \mathrm{L}^{-1}$ ABTS solution with $0.44 \mathrm{~mL}$ of an aqueous $140 \mathrm{mmol} \mathrm{L}^{-1}$ solution of potassium persulfate. The reaction was kept in the dark for $16 \mathrm{~h}$, and $2 \mathrm{~mL}$ of this solution was then dissolved in absolute ethanol until it reached an absorbance of $0.700 \pm 0.005$ at $734 \mathrm{~nm}$.

The reaction consisted of mixing $50 \mu \mathrm{L}$ of a methanolic extract solution $\left(0.2 \mathrm{mg} \mathrm{mL}^{-1}\right)$ with $5 \mathrm{~mL}$ of the final $\mathrm{ABTS}^{*+}$ solution. After $6 \mathrm{~min}$, the absorbance of the reaction was measured at $734 \mathrm{~nm}$ using absolute ethanol as a blank. ${ }^{14}$ The $\mathrm{ABTS}^{++}$solution was daily prepared, and the reactions were carried out in the dark. All reactions were done in triplicate. The obtained absorbance values were plotted in a Trolox curve (Sigma-Aldrich Chemie, Steinheim, Germany; 0.000-2.400 $\mathrm{mmol} \mathrm{L}^{-1}$; $y=-26.37778 x+0.65164 ; R=-0.9997)$, and the results were expressed in mmol TE $100 \mathrm{~g}^{-1}$.

Antioxidant activity using FRAP (ferric reducing antioxidant power)

The FRAP assay was done to access the ability of the honey extracts to reduce the ferric 2,4,6-tripyridyl-s-triazine complex $\left(\mathrm{Fe}^{3+}\right.$-TPTZ complex) to its blue ferric form ( $\mathrm{Fe}^{2+}$-TPTZ complex). The FRAP reagent was daily prepared by mixing $10 \mathrm{~mL}$ of an aqueous $10 \mathrm{mmol} \mathrm{L}^{-1} \mathrm{TPTZ}$ 
(2,4,6-tripyridyl-s-triazine) solution in $40 \mathrm{mmol} \mathrm{L}^{-1} \mathrm{HCl}$, $10 \mathrm{~mL}$ of a $20 \mathrm{mmol} \mathrm{L}^{-1} \mathrm{FeCl}_{3}$ solution and $100 \mathrm{~mL}$ of a $0.3 \mathrm{~mol} \mathrm{~L}^{-1}$ acetate buffer ( $\mathrm{pH}$ 3.6). The reaction was then carried out by mixing $0.5 \mathrm{~mL}$ of a methanolic extract solution $\left(0.2 \mathrm{mg} \mathrm{mL}^{-1}\right)$ with $4.5 \mathrm{~mL}$ of the FRAP reagent, and the absorbance was measured at $593 \mathrm{~nm}$ after incubation for 10 min at $37{ }^{\circ} \mathrm{C} .{ }^{15}$ All reactions were done in triplicate. The blank consisted of $0.5 \mathrm{~mL}$ of methanol in $4.5 \mathrm{~mL}$ of the FRAP reagent. The absorbance values were plotted on a $\mathrm{FeSO}_{4} \cdot 7 \mathrm{H}_{2} \mathrm{O}$ curve (Vetec, Brazil; 100-1000 $\mu \mathrm{mol} \mathrm{L}{ }^{-1}$; $y=0.0018 x+0.00107, R=0.99961)$, and the results were expressed in mmol Fe(II) $100 \mathrm{~g}^{-1}$.

\section{HPLC analysis of the phenolic profile of honey}

Polyphenol identification analyses were carried out using a liquid chromatograph (LC-20AT, Shimadzu, Japan) with a diode array detector (DAD, SPD-M20A) coupled to an LCSolution ChemStation data-processing station. The column used was a $\mathrm{C}_{18}$ LiChroCART $(250 \mathrm{~mm} \times 4 \mathrm{~mm}$; $5 \mu \mathrm{m}$; Merck, Darmstadt, Germany), operated at $35^{\circ} \mathrm{C}$. The mobile phase consisted of solvent $\mathrm{A}$ (water and acetic acid, 99:1) and solvent B (water, acetonitrile and acetic acid, 59:40:1). The gradient program was as follows: from 25 to $100 \% \mathrm{~B}$ in $30 \mathrm{~min}$, and then isocratic by $10 \mathrm{~min}$. The injection volume was $20 \mu \mathrm{L}$, and the flow rate was

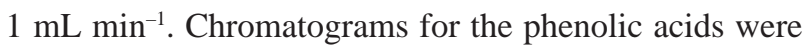
recorded at $270 \mathrm{~nm}$ and for flavonoids at $360 \mathrm{~nm}$. The identification of phenolic compounds was based on a comparison of chromatographic data (retention times and UV spectra) with authentic markers, while quantification was performed through external calibration data with the same compounds. Quantitative results were expressed as mg of compound per $100 \mathrm{~g}$ of honey.

Authentic markers available at the market were used for chromatographic comparison of data. Gallic acid, protocatechuic acid, syringic acid, $p$-hydroxybenzoic acid, sinapic acid, vanillic acid, $p$-coumaric acid, $p$-methoxybenzoic acid, cinnamic acid, rutin, isoquercetin, morin and quercetin were supplied by Sigma-Aldrich Chemie (Steinheim, Germany).

\section{Statistical analysis}

Differences in percentage antioxidants, the total phenolics and the correlations between the phenolic content in honey and its antioxidant activity were analyzed applying the software Unscrambler X version 10.1. Significance level was $p<0.01$ unless otherwise indicated, and correlation coefficients $R$ varied from 0.99006 to 0.99956 .

\section{Results and Discussion}

Nine honey samples of different floral origins and their respective extracts were tested to evaluate their antioxidant properties and to find the relationship of total phenolic contents, flavonoid contents and antioxidant activity with floral and geographical origins. The total phenolic (TP) contents varied from 34.0 to $78.2 \mathrm{mg} \mathrm{GAE} 100 \mathrm{~g}^{-1}$ for

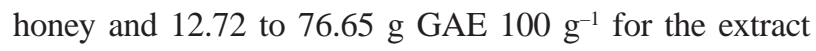
(Tables 2 and 3). The multifloral honey (sample RLS1)

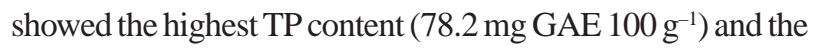
highest radical scavenging activity $\left(\mathrm{RSA}=10.81 \mathrm{mg} \mathrm{mL}^{-1}\right)$, while the orange blossom honey extract RLL1 showed the highest phenolic content and also the highest

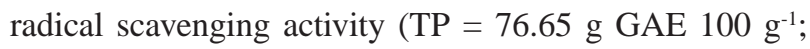
RSA $5.48 \mu \mathrm{g} \mathrm{mL}^{-1}$ ). The GAE values for individual honey samples confirmed that the phenolic contents are significantly dependent on the floral sources, which is in agreement with other previous data. ${ }^{2,16}$

Table 2. Total phenolic (TP) and total flavonoid (TF) contents and radical scavenging activity $\left(\mathrm{EC}_{50}\right)$ of the honey samples ${ }^{\mathrm{a}}$

\begin{tabular}{|c|c|c|c|}
\hline Honey & $\begin{array}{c}\mathrm{TP} / \\
\left(\mathrm{mg} \mathrm{GAE} 100 \mathrm{~g}^{-1}\right)\end{array}$ & $\begin{array}{c}\mathrm{TF} / \\
\left(\mathrm{mg} \mathrm{QE} 100 \mathrm{~g}^{-1}\right)\end{array}$ & $\begin{array}{c}\text { Radical scavenging } \\
\text { activity (RSA) } \\
\mathrm{EC}_{50} /\left(\mathrm{mg} \mathrm{mL}^{-1}\right)\end{array}$ \\
\hline RLS1 & $78.2 \pm 2.7$ & - & $10.81 \pm 0.50$ \\
\hline RLS2 & $42.8 \pm 1.9$ & $0.25 \pm 0.03$ & $19.74 \pm 1.62$ \\
\hline RLS3 & $57.2 \pm 2.4$ & $1.60 \pm 0.16$ & $18.42 \pm 1.47$ \\
\hline RLS4 & $54.0 \pm 2.3$ & $4.27 \pm 0.43$ & $17.52 \pm 1.10$ \\
\hline Mean & $58.05 \pm 14.78$ & $1.53 \pm 1.96$ & $16.62 \pm 3.98$ \\
\hline RLL1 & $35.7 \pm 2.4$ & $0.30 \pm 0.03$ & $36.22 \pm 3.82$ \\
\hline RLL2 & $38.8 \pm 3.6$ & $0.28 \pm 0.04$ & $40.80 \pm 4.68$ \\
\hline RLL3 & $53.2 \pm 2.9$ & - & $29.85 \pm 2.67$ \\
\hline RLL4 & $40.1 \pm 2.9$ & - & $33.21 \pm 2.51$ \\
\hline RLL5 & $34.0 \pm 1.8$ & $0.24 \pm 0.01$ & $52.64 \pm 4.70$ \\
\hline Mean & $40.36 \pm 7.58$ & $0.17 \pm 0.15$ & $38.54 \pm 8.85$ \\
\hline
\end{tabular}

${ }^{a}$ All data expressed on a honey weight basis as means $\pm \operatorname{SD}(n=3)$.

The total flavonoid (TF) contents of the honey samples and their extracts were also determined. Flavonoid content was lower than phenolic content and ranged from

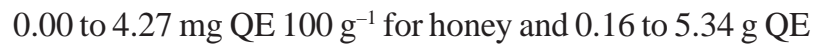
$100 \mathrm{~g}^{-1}$ for the extracts (Tables 2 and 3). The greatest TF content was reported for the multifloral honey RLS4 (4.27 mg QE $100 \mathrm{~g}^{-1}$ ) and the orange blossom honey extract RLL1 (5.34 g QE $100 \mathrm{~g}^{-1}$ ).

The TP average values found for the analyzed samples are higher than those previously reported in honeys from other origin, such as Cuban honeys (21.39-59.58 mg GAE $\left.100 \mathrm{~g}^{-1}\right){ }^{16}$ and Czech honeys 
Table 3. Total phenolic (TP) and total flavonoid (TF) contents, DPPH, ABTS and FRAP tests of the honey extracts ${ }^{\mathrm{a}}$

\begin{tabular}{|c|c|c|c|c|c|}
\hline Extract & TP / $\left(\mathrm{g}_{\text {GAE }} 100 \mathrm{~g}^{-1}\right)$ & $\mathrm{TF} /\left(\mathrm{g}\right.$ QE $\left.100 \mathrm{~g}^{-1}\right)$ & FRAP / (mol Fe(II) $\left.100 \mathrm{~g}^{-1}\right)$ & $\mathrm{ABTS} /\left(\mathrm{mmol}\right.$ TE $\left.100 \mathrm{~g}^{-1}\right)$ & $\mathrm{DPPH}: \mathrm{EC}_{50} /\left(\mu \mathrm{g} \mathrm{mL}^{-1}\right)$ \\
\hline RLS1 & $25.60 \pm 0.37$ & $0.50 \pm 0.01$ & $95.18 \pm 3.21$ & $137.79 \pm 4.82$ & $51.45 \pm 5.59$ \\
\hline RLS2 & $71.76 \pm 1.52$ & $0.95 \pm 0.01$ & $408.14 \pm 10.02$ & $316.48 \pm 9.82$ & $8.17 \pm 0.27$ \\
\hline RLS3 & $24.22 \pm 0.49$ & $0.30 \pm 0.01$ & $109.99 \pm 11.23$ & $125.67 \pm 9.95$ & $37.62 \pm 1.99$ \\
\hline RLS4 & $30.05 \pm 0.83$ & $0.38 \pm 0.02$ & $78.51 \pm 4.24$ & $58.66 \pm 15.20$ & $30.60 \pm 2.33$ \\
\hline Mean & $37.91 \pm 22.71$ & $0.53 \pm 029$ & $172.96 \pm 157.32$ & $159.65 \pm 110.19$ & $31.96 \pm 18.07$ \\
\hline RLL1 & $76.65 \pm 0.56$ & $5.34 \pm 0.03$ & $438.69 \pm 2.78$ & $383.49 \pm 6.15$ & $5.48 \pm 0.03$ \\
\hline RLL2 & $50.39 \pm 1.18$ & $0.23 \pm 0.01$ & $376.66 \pm 1.60$ & $236.71 \pm 3.32$ & $10.50 \pm 0.39$ \\
\hline RLL3 & $47.62 \pm 0.74$ & $0.16 \pm 0.01$ & $375.73 \pm 6.99$ & $207.99 \pm 3.83$ & $10.73 \pm 0.20$ \\
\hline RLL4 & $12.72 \pm 0.32$ & $0.19 \pm 0.01$ & $34.99 \pm 4.24$ & $46.53 \pm 1.11$ & $52.87 \pm 1.10$ \\
\hline RLL5 & $40.97 \pm 0.73$ & $0.34 \pm 0.01$ & $303.51 \pm 1.60$ & $210.54 \pm 4.42$ & $16.16 \pm 0.47$ \\
\hline Mean & $45.67 \pm 22.88$ & $1.25 \pm 2.89$ & $305.92 \pm 158.84$ & $217.05 \pm 119.68$ & $15.22 \pm 10.75$ \\
\hline
\end{tabular}

${ }^{a}$ All data expressed on extract weight basis as means $\pm \operatorname{SD}(n=3)$.

(8.99-21.52 mg GAE $\left.100 \mathrm{~g}^{-1}\right) .{ }^{10}$ However, the results obtained for TF $\left(0.25-4.27 \mathrm{mg}\right.$ QE $\left.100 \mathrm{~g}^{-1}\right)$ are lower than values as previously reported for other honeys, such as Portuguese honey (12.36-58.74 mg QE $\left.100 \mathrm{~g}^{-1}\right),{ }^{17}$ Tualang honey (4.74-22.76 mg QE $\left.100 \mathrm{~g}^{-1}\right)^{18}$ and Indian honey (4.23-0.10 mg QE $\left.100 \mathrm{~g}^{-1}\right) .{ }^{19}$

The radical scavenging activities (RSA) of the different honeys and phenolic extracts are also summarized in Tables 2 and 3. The radical scavenging activities of the honey samples, expressed as DPPH-EC ${ }_{50}$, varied from 10.81 to $52.64 \mathrm{mg} \mathrm{mL}^{-1}$. The antioxidant capacity was high and widely differed among the honey samples. The lowest scavenging activity was found in the orange blossom honey RLL5 (52.64 $\mathrm{m} \mathrm{mL}^{-1}$ ) while the highest activity was found in the multifloral honey RLS1 $\left(10.81 \mathrm{mg} \mathrm{mL}^{-1}\right)$. The highest average RSA was observed for multifloral honey samples $\left(16.62 \mathrm{mg} \mathrm{mL}^{-1}\right)$, though the multifloral extracts showed lower antioxidant activity than orange blossom honey extracts. Most likely, the differences in antioxidant activity between the tested samples mainly depend on the floral source of honey.

The radical scavenging capacities of the tested honey extracts were also evaluated in FRAP and $\mathrm{ABTS}^{-+}$radical reaction systems. All honey extracts exhibited scavenging potential towards both radicals.

The observed range of FRAP values [ $438.69 \mathrm{mmol} \mathrm{Fe}$ (II) to $34.99 \mathrm{mmol} \mathrm{Fe}$ (II)] for honey extracts is comparable to the reducing capacity range of raw Millefiori honey. A range of 61.75-124.5 mmol Fe(II) was found for monofloral honeys ${ }^{20}$ and a range of 71.0-478.5 mol Fe(II) was found for heterofloral honey samples. ${ }^{21}$

Based on the correlation matrices (Tables 4 and 5), each coefficient was considered in order to establish the correlations between different couples of assays. The highly significant correlation between total phenol content and DPPH activity $(R=-0.8146, p<0.01)$ of honeys suggests that phenolics are the major components responsible for the antioxidant effects. Similarly, the correlations of antioxidant activity with TP content were also apparent in the extracts $(-0.8918 \leq R \leq 0.9580, p<0.01)$.

Table 4. Correlation matrix between the results of total phenolic (TP) and total flavonoid (TF) contents and DPPH for the honey samples

\begin{tabular}{lccc}
\hline & $\mathrm{TP}$ & $\mathrm{TF}$ & $\begin{array}{c}\text { DPPH:EC } \\
\text { (honey) }\end{array}$ \\
\hline $\mathrm{TP}$ & 1 & - & - \\
$\mathrm{TF}$ & 0.1759 & 1 & - \\
$\begin{array}{l}\text { DPPH:EC } \\
\text { (honey) }\end{array}$ & -0.8146 & -0.3704 & 1 \\
\hline
\end{tabular}

As shown in Table 5, there were high correlations among the three methods for antioxidant activity measurement $(-0.8257 \leq R \neq 0.9457, p<0.01)$, which could be confirmed by the linear correlation graphics shown in Figure 1, indicating a great degree of equivalence among these measurements. There was also a correlation

Table 5. Correlation matrix between the results of total phenolic (TP) and total flavonoid (TF) contents, FRAP, ABTS and DPPH for the extracts

\begin{tabular}{|c|c|c|c|c|c|}
\hline & $\mathrm{TP}$ & $\mathrm{TF}$ & FRAP & ABTS & $\mathrm{DPPH}: \mathrm{EC}_{50}$ (extract) \\
\hline TP & 1 & - & - & - & - \\
\hline $\mathrm{TF}$ & 0.6558 & 1 & - & - & - \\
\hline FRAP & 0.9258 & 0.4693 & 1 & - & - \\
\hline ABTS & 0.9580 & 0.6917 & 0.9259 & 1 & - \\
\hline DPPH:EC ${ }_{50}$ (extract) & -0.8918 & -0.4108 & -0.9457 & -0.8257 & 1 \\
\hline
\end{tabular}



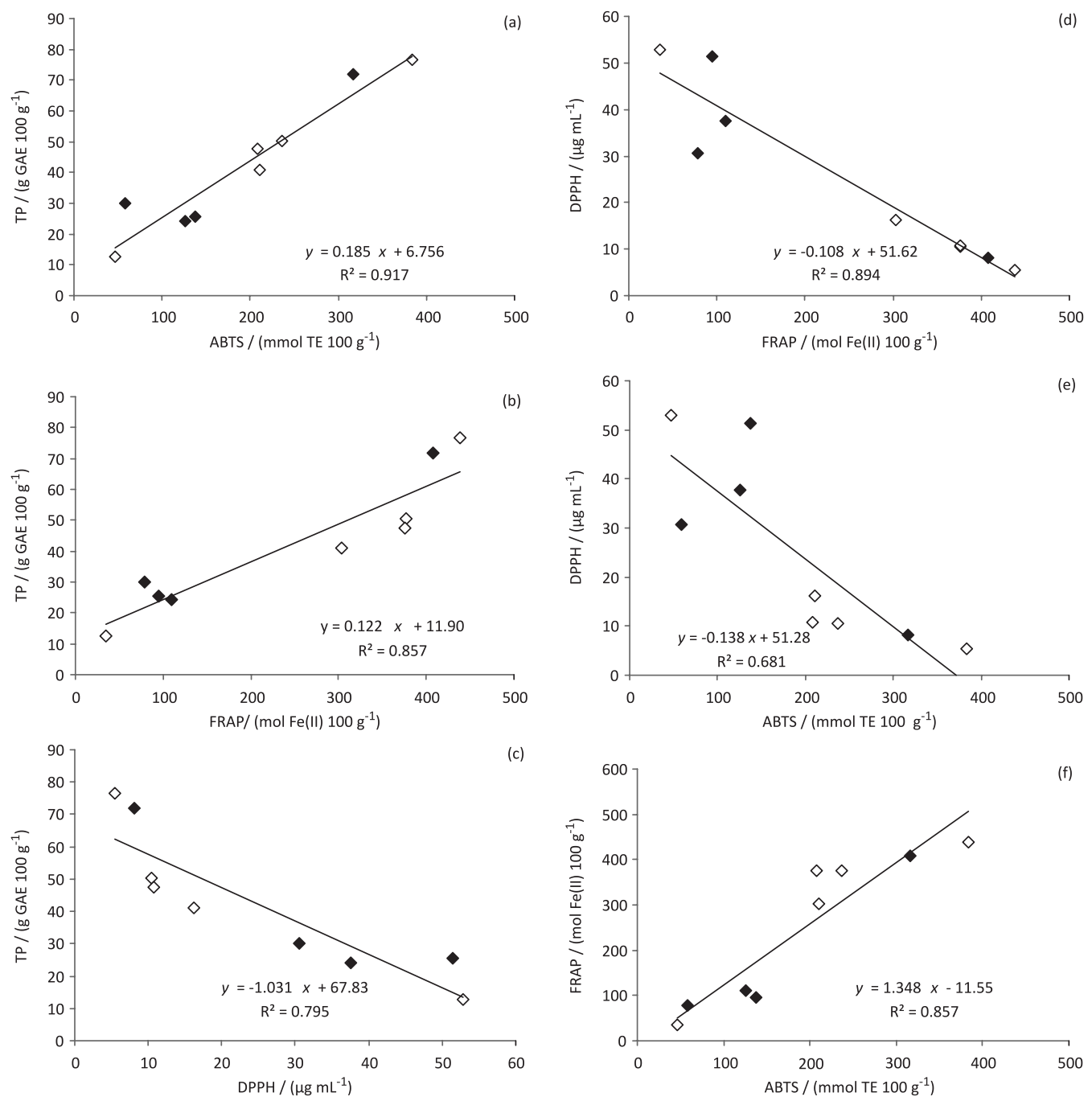

Figure 1. Linear correlations for the extracts between: (a) TP and ABTS, (b) TP and FRAP, (c) TP and DPPH, (d) DPPH and FRAP, (e) DPPH and ABTS, and (f) FRAP and ABTS. White dots: orange blossom honey extracts and black dots: multifloral honey extracts.

with the total phenolic contents. Figures $1 \mathrm{a}-1 \mathrm{c}$ show the correlation of the total phenolic compounds of the extract with ABTS, FRAP and DPPH, respectively, while Figures 1d-1f show the correlation between each of these antioxidant activity methods using the results obtained for the extracts.

The lower correlation and poor statistical significance obtained for total flavonoid content and the honey antioxidant activities $(R=-0.3704 ; p=0.2)$ were assumed to be caused by the very low flavonoid concentration in honey, which eventually reached zero. Although flavonoids are well known to have many important biological properties, including antioxidant activity, their low content in the analyzed honeys made them poor contributors to overall antioxidant capacity of honeys.

The darker multifloral honeys showed higher antioxidant activities and phenolic content than the lighter orange blossom honeys, though the pattern was different for the extracts. The orange blossom honey extracts showed much better results than the multifloral extracts, especially in sample RLL2 (5.48 $\mu \mathrm{g} \mathrm{mL}^{-1}$ for DPPH), which may be due to the extraction process. It is known that minerals, especially iron, can complex with phenolic compounds, enhancing their antioxidant activity and color. ${ }^{22}$ The water cleansing process during Amberlite XAD-2 extraction can remove most of the honey mineral contents, as their complexes are mainly water soluble. In addition, glycosylated phenolic compounds, which can also contribute to antioxidant capacity of honey, may not be extracted to the methanolic phase or they may be lost in the aqueous phase. Therefore, there might be considerable changes in antioxidant activity and phenolic compounds when comparing the honey and its extract.

It was reported that phenolic compounds are the main components responsible for the antioxidant effects of honey, though some other compounds may also be 
involved. Therefore, the evaluation of total phenolic contents and antioxidant activities of honeys may be used as parameters for the assessment of honey quality, as well as the identification of the phenolic constituents. ${ }^{3,23}$

The composition profile of phenolic compounds was analyzed by HPLC. Chromatographic analysis also showed that phenolic acids prevailed in the multifloral honeys.

These results coincide with the results obtained by the
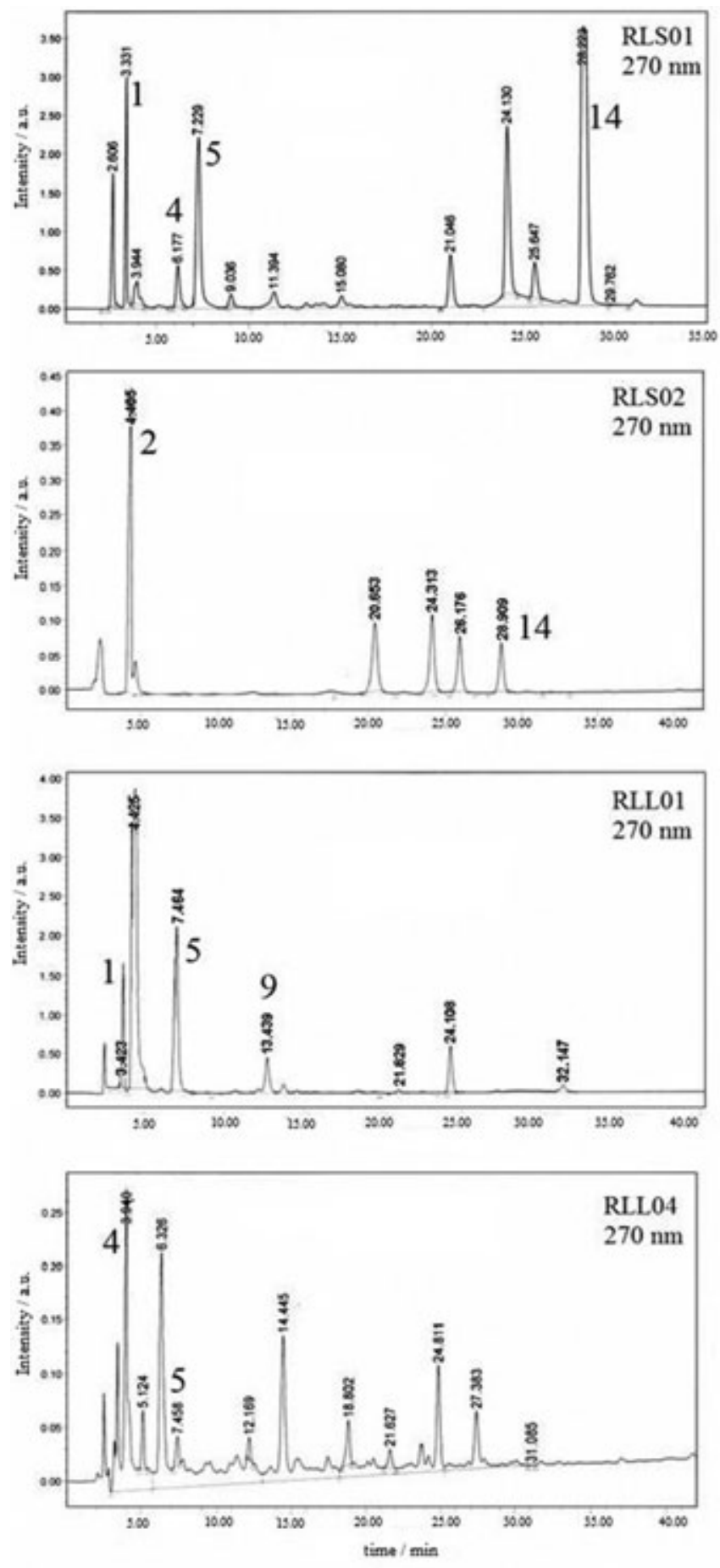

Folin-Denis method (Table 2): multifloral honey contained a high amount of phenolic compounds, while in orange honey it was the lowest.

The composition and content of individual phenolic compounds in the samples were different and depended on the botanical origin of honeys. Figure 2 shows the typical HPLC chromatograms obtained for some orange blossom and multifloral honey extracts.
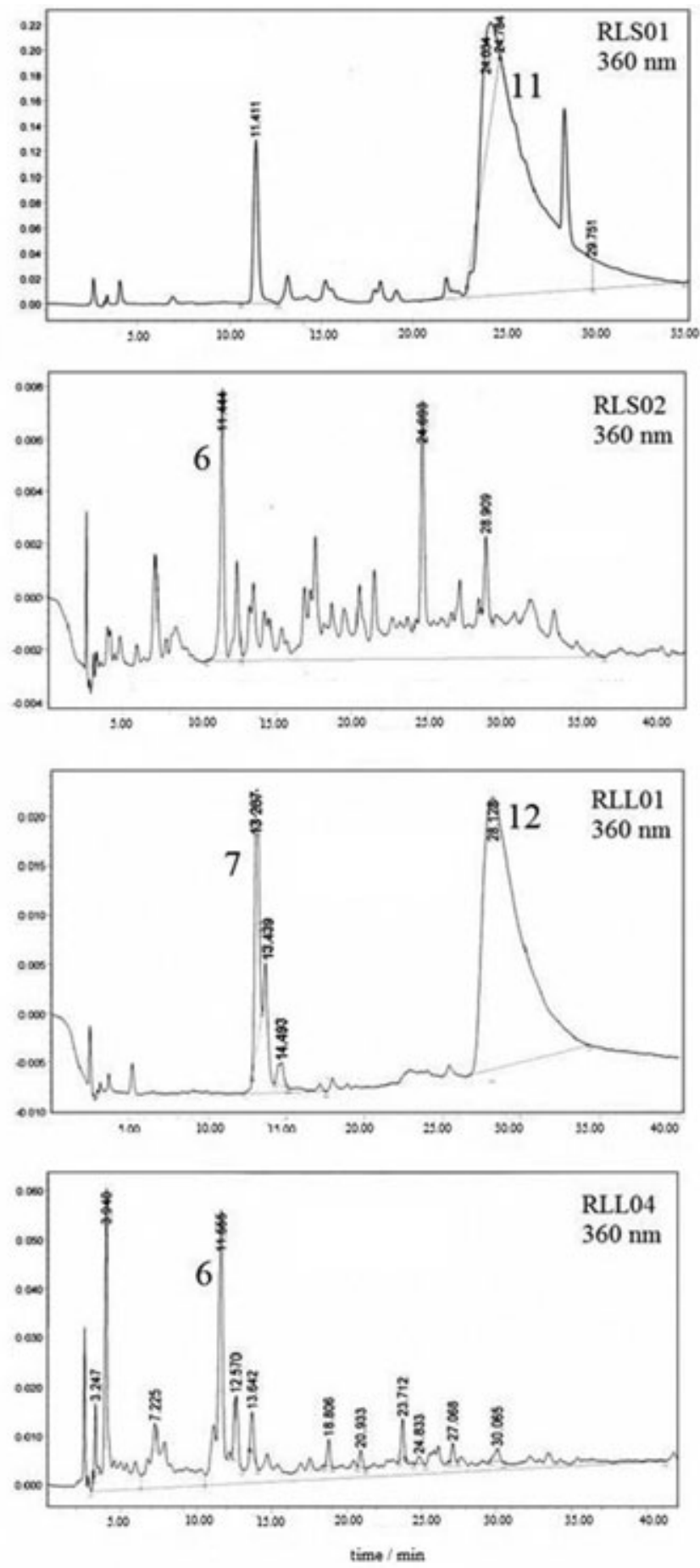

Figure 2. HPLC chromatograms of multifloral and orange blossom honey extracts. For peak identification, see Table 6. 
About fourteen phenolic compounds were identified (four flavonoids and ten phenolic acids) and the phenolic pattern of honey contained gallic acid, protocatequic acid, syringic acid, $p$-hydroxibenzoic acid, vanillic acid, $p$-coumaric acid, sinapic acid, $p$-methoxybenzoic acid, cinnamic acid and $p$-methoxycinnamic acid, as well as the flavonoids rutin, isoquercetin, morin and quercetin. Some of these identified phenolic compounds were already reported in other honeys. ${ }^{2,6}$ The results of the quantitative determination of phenolic acids and flavonoids in those types of honeys are presented in Table 6. Among these compounds, phenolic acids showed higher concentrations than flavonoids. Some other compounds present in the chromatogram that had similar flavonoid and phenolic acid spectra and chromatographic behavior but they could not be identified due to lack of availability of standard compounds. Comparison with other values found in literature is difficult since previous studies employed different sample preparation and extraction conditions to those used in this work. ${ }^{24}$

The radical scavenging activities of the identified phenolic compounds were also screened in order to evaluate their possible contribution to antioxidant capacity of extracts. Their retention times, $\lambda_{\max }(\mathrm{nm})$ and antioxidant activity (expressed as $\mathrm{EC}_{50}$ ) are related in Table 7.

According to Table 7, the most hydroxylated compounds, especially in ortho positions such as quercetin and gallic acid,

Table 6. Contents of phenolic compounds in the honey samples (mg $100 \mathrm{~g}^{-1}$ honey)

\begin{tabular}{|c|c|c|c|c|c|c|c|c|c|c|}
\hline \multirow{2}{*}{ entry } & \multirow{2}{*}{ Phenolic compound } & \multicolumn{4}{|c|}{ Multifloral honey } & \multicolumn{5}{|c|}{ Orange blossom honey } \\
\hline & & RLS1 & RLS2 & RLS3 & RLS4 & RLL1 & RLL2 & RLL3 & RLL4 & RLL5 \\
\hline 1 & Gallic acid & 7.278 & - & - & - & 0.005 & - & - & - & - \\
\hline 2 & Protocatechuic acid & - & 0.881 & 0.967 & - & - & 1.040 & 6.673 & - & 1.307 \\
\hline 3 & Syringic acid & - & - & - & - & - & - & - & - & 1.376 \\
\hline 4 & $p$-Hydroxybenzoic acid & 9.805 & - & 3.680 & 5.813 & - & - & - & 0.823 & - \\
\hline 5 & Vanillic acid & 17.154 & - & - & 2.895 & 21.152 & - & - & 0.142 & - \\
\hline 6 & $p$-Coumaric acid & - & 0.033 & 7.770 & 7.788 & - & 0.515 & - & 0.671 & 0.905 \\
\hline 7 & Rutin & - & - & - & - & 0.389 & - & - & - & - \\
\hline 8 & Isoquercetin & - & - & - & 2.960 & - & - & - & - & - \\
\hline 9 & Sinapic acid & 0.699 & - & - & - & 9.102 & 3.980 & - & - & - \\
\hline 10 & $p$-Methoxybenzoic acid & - & - & 9.015 & 7.855 & - & - & - & - & - \\
\hline 11 & Morin & 20.268 & - & - & 1.773 & - & - & - & - & - \\
\hline 12 & Quercetin & - & - & 2.942 & - & 2.169 & - & - & - & - \\
\hline 13 & Cinnamic acid & - & - & - & - & - & 0.304 & - & - & 0.219 \\
\hline 14 & $p$-Methoxycinnamic acid & 22.453 & 0.254 & - & - & - & 1.935 & - & - & 0.754 \\
\hline
\end{tabular}

Table 7. Phenolic standards, retention times, maximum absorption and radical scavenging activity $\left(\mathrm{EC}_{50}\right)$ of the identified phenolic compounds

\begin{tabular}{lcccc}
\hline entry & Phenolic compound & $\mathrm{t}_{\mathrm{R}} / \mathrm{min}$ & $\lambda_{\max } / \mathrm{nm}$ & $\mathrm{EC}_{50}{ }^{\mathrm{b}} /\left(\mu \mathrm{mol} \mathrm{L}^{-1}\right)$ \\
\hline 1 & Gallic acid & 3.404 & 272 & $6.83 \pm 0.04$ \\
2 & Protocatechuic acid & 4.190 & 259,295 & $14.97 \pm 0.84$ \\
3 & Syringic acid & 5.936 & 274 & $12.24 \pm 0.27$ \\
4 & $p$-Hydroxybenzoic acid & 6.325 & 256 & $1502.15 \pm 25.81$ \\
5 & Vanillic acid & 7.509 & 260,292 & $131.07 \pm 6.24$ \\
6 & $p$-Coumaric acid & 11.377 & 310 & $239.74 \pm 2.78$ \\
7 & Rutin & 13.292 & 256,354 & $7.62 \pm 0.11$ \\
8 & Isoquercetrin & 13.409 & 256,354 & $9.33 \pm 0.36$ \\
9 & Sinapic acid & 13.572 & $294 s h^{\mathrm{a}}, 323$ & $20.60 \pm 0.47$ \\
10 & $p$-Methoxybenzoic acid & 19.969 & 257 & $2821.68 \pm 118.55$ \\
11 & Morin & 25.114 & 252,353 & $16.34 \pm 0,38$ \\
12 & Quercetin & 27.416 & 256,368 & $6.46 \pm 0.06$ \\
13 & Cinnamic acid & 27.669 & 278 & $3040.07 \pm 37.75$ \\
14 & $p$-Methoxycinnamic acid & 28.797 & 306 & $1363.71 \pm 51.47$ \\
\hline
\end{tabular}

${ }^{\mathrm{a}} \mathrm{s}=$ shoulder; ${ }^{\mathrm{b}}$ radical scavenging activity was expressed as DPPH-EC ${ }_{50}$. 
showed the highest antioxidant activities $\left(\mathrm{EC}_{50}=6.46\right.$ and $6.83 \mu \mathrm{mol} \mathrm{L}{ }^{-1}$, respectively), while the least hydroxylated compounds showed inferior antioxidant activities.

Accordingly, the honey extract RLL1, with the highest antioxidant activity $\left(\mathrm{EC}_{50}=5.48 \mu \mathrm{g} \mathrm{mL}^{-1}\right)$ showed the presence of quercetin, rutin and gallic acid (2.169, 0.389 and $0.005 \mathrm{mg} 100 \mathrm{~g}^{-1}$ of honey, respectively), and also considerable amounts of vanillic and sinapic acids

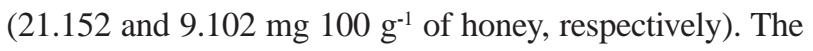
honey extract RLL4, with the least antioxidant capacity $\left(\mathrm{EC}_{50}=52.87 \mu \mathrm{g} \mathrm{mL}^{-1}\right)$ showed the presence of only three phenolic compounds in low amounts: $p$-hydroxybenzoic (0.823 mg $100 \mathrm{~g}^{-1}$ of honey), vanillic $\left(0.142 \mathrm{mg} 100 \mathrm{~g}^{-1}\right.$ of honey) and $p$-coumaric $\left(0.671 \mathrm{mg} 100 \mathrm{~g}^{-1}\right.$ of honey) acids, which have low antioxidant activities (Table 7; entries 4,5 and 6 , respectively). Although it had the highest antioxidant activity $\left(\mathrm{EC}_{50}=8.17 \mu \mathrm{g} \mathrm{mL} \mathrm{mL}^{-1}\right)$, the honey extract RLS2 showed the presence of only three

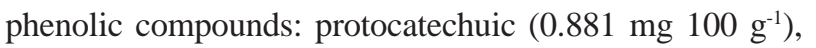

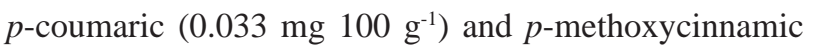
$\left(0.254 \mathrm{mg} 100 \mathrm{~g}^{-1}\right)$ acids. As these compounds exhibit different antioxidant properties, they should influence the RSA of the tested honey samples. These findings show that other components, which were not analyzed in our study, should also play an important role in defining RSA of honey.

Though being more valorized among consumers because of its characteristic flavor, light color and scent, the orange blossom honeys studied in this work generally had poorer phenolic contents and antioxidant capacities when compared to the multifloral honeys. That may be due to characteristic secondary metabolism of citric plant, or even to a wider nectar and pollen source in multifloral areas. Therefore, the less appealing and less expensive multifloral honeys should be more popularized among consumers because of their prominent functional properties.

\section{Conclusions}

The present study shows that different honeys contain high levels of phenolics and flavonoids and that the distribution of these compounds is influenced by the floral origin of honey. The antioxidant capacity in multifloral honey was higher than in orange blossom honeys, which could be related to their higher phenolic contents. Orange blossom honeys had lower amounts of phenolic compounds, but they also showed good radical scavenging activity, though less than that seen in multifloral honeys. Phenolic acids prevailed in the all samples. Therefore, the analyzed honeys may be considered easily accessible natural sources of antioxidants and valuable additions to the everyday diet.
HPLC-DAD analysis showed that the extracts are particularly rich in a variety of phenolic acids including $p$-coumaric, protocatechuic, $p$-methoxybenzoic, $p$-hydroxybenzoic and $p$-methoxycinnamic acids, and the flavonoids quercetin and morin. However, the content of individual compounds was different.

The phenolic fractions had much lower $\mathrm{EC}_{50}$ values than the corresponding honey. Orange blossom honey extracts showed higher antioxidant capacities and phenolic content than multifloral honey extracts, in contrast to what was observed for honey. Finally, the total antioxidant capacity of honey is likely the result of the combined activities and interactions of a wide range of compounds, including organic acids, enzymes, and possibly other minor components. However, phenolic compounds are well known to be the major contributors of this property, enriching honey quality as a functional food. These results revealed that the Brazilian honeys studied proved to be a good source of antioxidants that might serve to protect human health.

\section{Acknowledgement}

The authors thank Fundação de Amparo à Pesquisa do Estado do Rio de Janeiro (FAPERJ), Coordenação de Aperfeiçoamento de Pessoal de Nível Superior (CAPES) and Conselho Nacional de Desenvolvimento Científico e Tecnológico (CNPq) for the financial support.

\section{References}

1. Cherchi, A.; Spanedda, L.; Tuberoso, C.; Cabras, P.; J. Chromatogr., A 1994, 669, 59.

2. Gheldof, N.; Wang, X. H.; Engeseth, N. H.; J. Agric. Food Chem. 2002, 50, 5870.

3. Pyrzynska, K.; Biesaga, M.; TrAC, Trends Anal. Chem. 2009, 28, 893; Dimitrova, B.; Gevrenova, R.; Anklam, E.; Phytochem. Anal. 2007, 18, 24.

4. Smchram, D. D.; Karim, M.; Schrader, H. R.; Holt, R. R.; Cardeti, M.; Keen, C. L.; J. Agric. Food Chem. 2003, 51, 1732; Al-Mamary, M.; Al-Meeri, A.; Al-Habori, M.; Nutr. Res. 2002, 22, 1041 .

5. Chen,L.; Mechta,A.; Berebaum, M.;Zangerl,A. R.; Egeseth, N.J.; J.Agric. Food Chem. 2000, 48, 4997; Frankel, S.; Robinson, G. E.; Berenbaum, M. R.; J. Apic. Res. 1998, 37, 27.

6. Al, M. L.; Daniel, D.; Moise, A.; Bobis, O.; Laslo, L.; Bogdanov, S.; Food Chem. 2009, 112, 863; Ferreira, I. C. F. R.; Aires, E.; Barreira, J. C. M.; Estevinho, L. M.; Food Chem. 2009, 114, 1438; Socha, R.; Juszczak, L.; Pietrzyk, S.; Food Chem. 2009, 113, 568; Siddhuraju, P.; Becker, K.; Food Chem. 2007, 101, 10 . 
7. Martos, I.; Ferreres, F.; Tomás-Barberán, F. A.; J. Agric. Food Chem. 2000, 48, 1498; Tomás-Barberán, F. A.; Martos, I.; Ferreres, F.; Radovic, B. S.; Anklam, E.; J. Sci. Food Agric. 2001, 81, 485; Escriche, I.; Kadar, M.; Juan-Borrás, M.; Domenech, E.; Food Res. Int. 2011, 44, 1504.

8. Punt, W.; Hoen, P. P.; Blackmore, S.; Nilsson, S.; Le Thomas, A.; Glossary of Pollen and Spore Terminology, $2^{\text {nd }}$ ed.; Review of Palaeobotany and Palynology: Utrecht, 2007; Barth, O. M.; O Pólen no Mel Brasileiro, 1a. ed.; Gráfica Luxor: Rio de Janeiro, Brasil, 1989, Louveaux, J.; Maurizzio, A.; Vorwohl, G.; Bee World 1978, 59, 139.

9. Lianda, R. L. P.; Castro, R. N.; Quim. Nova 2008, 31, 1472.

10. Singleton, V. L.; Orthofer, R.; Lamuela-Raventos, R. M.; Methods Enzymol. 1999, 299, 152; Helrick, K.; Official Methods of Analysis of the Association of Official Analytical Chemists, $15^{\text {th }}$ ed.; Association of Official Analytical Chemists: Arlington, 1990.

11. Meda, A.; Lamien, C. E.; Romito, M.; Millogo, J.; Nacoulma, O. G.; Food Chem. 2005, 91, 571.

12. Zhang, D.; Hamauzu, Y.; Food Chem. 2004, 88, 503.

13. Mensor, L. L.; Menezes, F. S.; Leitão, G. G.; Reis, A. S.; dos Santos, T. C.; Coube, C. S.; Leitão, S. G.; Phytother. Res. 2001, 15, 127.

14. Rufino, M. S. M.; Alves, R. E.; Brito, E. S.; Morais, S. M.; Sampaio, C. G.; Pérez-Jiménez, J.; Saura-Calixto, F. D.; Metodologia Científica: Determinação da Atividade Antioxidante Total em Frutas pela Captura do Radical Livre $A B T S^{\circ}$, Comunicado Técnico 128-EMBRAPA; EMBRAPA: Fortaleza, CE, Brasil, 2007.
15. Bertoncelj, J.; Dobersek, U.; Jamnik, M.; Golob, T.; Food Chem. 2007, 105, 822.

16. Alvarez-Suarez, J. M.; González-Paramás, A. M.; Santos-Buelga, C.; Battino, M.; J. Agric. Food Chem. 2010, 58, 9817.

17. Ferreira, I.; Aires, E.; Barreira, J.; Estevinho, L.; Food Chem. 2009, 114, 1438 .

18. Khalil, E. Md. I.; Mahaneem, M.; Jamalullail, S. M. S.; Alam, N.; Sulaiman, S. A.; J. ApiProduct ApiMedical Sci. 2011, 3, 04.

19. Jaganathan; S. K.; Mandal; S. M.; Jana; S. K.; Das; S.; Mandal, M.; Nat. Prod. Res. 2010, 24, 1295.

20. Blasa, M.; Candiracci, M.; Accorsi, A.; Piacentini, M. P.; Albertini, M. C.; Piatti, E.; Food Chem. 2006, 97, 217.

21. Giangiacomo Beretta, G.; Granata, P.; Ferrero, M.; Orioli, M.; Facino, R. M.; Anal. Chim. Acta 2005, 533, 185.

22. Gonzalez-Miret, M. L.; Terrab, A.; Hernanz, D.; FernandezRecamales, M. A.; Heredia, F. J.; J. Agric. Food Chem. 2005, 53, 2574; Maselev, D.; Kuntic, V.; J. Serb. Chem. Soc. 2007, 72,921 .

23. Aljadi, A. M.; Kamaruddin, M. Y.; Food Chem. 2004, 85, 513.

24. Michalkiewicz, A.; Biesaga, M.; Pyrzynska, K.; J. Chromatogr., A 2008, 1187, 18; Andrade, P.; Ferreres, F.; Amaral, M. T.; J. Liq. Chromatogr. Relat. Technol. 1997, 20, 2281.

Submitted: July 26, 2011 Published online: February 7, 2012 